\title{
PENERAPAN PRINSIP DEMOKRASI EKONOMI, KEADILAN DAN KEPASTIAN HUKUM DALAM HUKUM PENANAMAN MODAL
}

\author{
Oleh : \\ Ronny Winarno
}

\begin{abstract}
System of Perekomonian Indonesia embrace the Economic Democracy under colour of familiarity ground affirmed in Section 33 article 4 UUD 1945 ( after amandemen) the executed principally is togetherness, efficiency with justice have, continuation, with vision of environment, independence, and also by balancing economic union and progress national, thereby prosperity do]not just to individual or group of people but for all people.
\end{abstract}

Keyword : Economic Democracy, Rule Of Law, Justice.

\section{PENDAHULUAN}

Pada tanggal 26 April 2007 telah diundangkan sekaligus diberlakukan Undang-Undang Nomor 25 Tahun 2007 tentang Penanaman Modal. Dengan berlakunya undang-undang ini maka undang-undang yang mengatur tentang penanaman modal sebelumnya dinyatakan tidak berlaku yaitu; Undang-Undang Nomor 1 Tahun 1967 tentang Penanaman Modal Asing (LNRI. Tahun 1967 Nomor I, TLNRI. No. 2818) sebagaimana telah dirubah dengan Undang-Undang Nomor II Tahun 1970 tentang Perubahan dan Tambahan. Undang-Undang Nomor I Tahun 1967 tentang Penanaman Modal Asing (LNRI. Tahun 1970 Nomor 46, TLNRI. Nomor 2943) dan UndangUndang Nomor 6 Tahun 1968 tentang
Penanaman Modal Dalam Negeri (LNRI. Tahun 1968 Nomor 33, TLNRI. No. 2853) sebagaimana telah diubah dengan Undang-Undang Nomor 12 Tahun 1970 tentang Perubahan dan Tambahan Undang-Undang Nomor 6 tahun 1968 tentang Penanaman Modal Dalam Negeri (LNRI Tahun 1970 Nomor 47, TLNRI. No. 2944).

Undang-Undang No. 25 Tahun 2007 tentang Penanaman Modal ini terdiri dari 18 bab dan 40 Pasal. Secara prinsip terdapat perbedaan yang sangat menonjol antara undang-undang penanaman modal yang lama dengan undang-undang penanaman modal yang baru. Perbedaan tersebut diantaranya adalah :

1. Dalam Undang-Undang No. 25 
Tahun 2007 tentang Penanaman Modal Pasal 3 ayat 1 menegaskan bahwa penanaman modal diselenggarakan berdasarkan asas : kepastian hukum. keterbukaan, akuntabilitas, perlakuan yang sama dan tidak membedakan asal negara, ke-bersamaan, efisiensi berkeadilan,berkelanjitan, berwawasan lingkungan, kemandirian, dan keseimbangan kctnajuan dan kesatuan ekonomi nasional. Dalam ketentuan undang-undang penanaman modal sebelumnya tidak mengatur yang demikian.

2. Adanya asas perlakuan yang sama dan tidak membedakan asal negara membawa konsekwensi yuridis pada hak, kewajiban, tanggungjawab serta fasilitas yang diberikan kepada pemodal pun tidak ada perbedaan. Undangundang penanaman modal sebelumnya memberikan perlakuan yang berbeda antara pemodal asing dengan pemodal dalam negeri.

3. Jangka waktu hak atas tanah, Undang-undang penanaman modal sebelumnya khususnya untuk penanaman modal asing jangka waktunya 30 tahun. Sedang untuk saat ini undangundang penanaman modal yang baru memberikan peluang yang panjang Hak Guna Usaha (HGU) dapat diberikan selama 95 tahun, Hak Guna Bangunan (HGB) selama 80 tahun dan Hak Pakai selama 70 tahun (pasa!22 ayat 1 Undang-Undang Nomor 25 Tahun 2007). Adanya ketentuan jangka waktu yang lama ini banyak menimbulkan polemik, lebih-lebih jika dikaitkan dengan tujuan negara untuk mewujudkan masyarakat adil dan makmur berdasarkan Pancasila dan Undang-Undang Dasar 1945. Ketentuan ini nampaknya justru akan menimbulkan bentukbentuk imperialisme baru, dimana hak-hak dan kepentingan rakyat kecil akan diabaikan, sebaliknya kepentingan pengusaha atau pemodal lebih diutamakan.

Selanjutnya apabila kita memperhatikan ketentuan konsideran menimbang dalam Undang-Undang Nomor 
25 Tahun 2007 tentang Penanaman Modal tersebut menegaskan bahwa tujuan dibentuknya undang-undang ini adalah:

1. Untuk mewujudkan masyarakat adil dan makmur berdasarkan Pancasiladan Undang-Undang Dasar 1945 perlu dilaksanakan pembangunan ekonomi nasional yang berkelanjutan dengan berlandaskan demokrasi ekonomi untuk mencapai tujuan bernegara.

2. Bahwa sesuai dengan amanat yang tercantum dalam Ketetapan Majelis Permusyawaratan Rakyat Republik Indonesi Nomor XVI/MPR/1998 tentang Politik Ekonomi dalam rangka Demokrasi Ekonomi, kebijakan penanaman modal selayaknya selalu mendasari ekonomi kerakyatan yang melibatkan pengembangan bagi usaha mikro, kecil, menengah dan koperasi.

3. Bahwa dalam menghadapi perubahan perekonomian global dan keikutsertaan Indonesia dalam berbagai kerjasama Internasional perlu diciptakan iklim penanaman modal yang kondusif, prmotif, memberikan kepastian hukum, keadilan dan efisiensi dengan tetap memperhatikan kepentingan ekonomi nasional.

Secara filosofis ada tujuan mulia dan agung yang ingin diwujudkan melalui undang undang penanaman modal ini. Namun apabila dicemati lebih dalam ternyata ada Pasal-Pasal yang justru kontroversi dengan tujuan tersebut. Setidaknya ada tiga hal yang dapat dicermati berkaitan dengan penerapan undang-undang penanaman modal yang baru ini, yakni: Demokrasi Ekonomi, Keadilan dan Kepastian Hukum.

\section{PEMBAHASAN.}

\section{Konsep demokrasi ekonomi}

Demokrasi Ekonomi berasal dari dua istilah yaitu; Demokrasi dan Ekonomi. Sesuai dengan asal katanya demokrasi berasal dari kata demos dan cratos atau pemerintahan oleh rakyat (ruled by the people).

Namun pengertian sejati tentang demokrasi sebenarnya sangatlah mendalam, bahkan bermacam-macam. Dalam 
mengartikan demokrasi biasanya ada 2 hal yang penting yaitu : sebagai falsafah hidup dan sebagai bentuk pemerintahan.

Sebagai falsafah hidup, demokrasi adalah suatu way of life yang memiliki dasar anggapan asasi bahwa :

- semua individu adalah sama

- semua individu itu memiliki hak yang sama pula dalam mengejar kebebasan dan kebahagiaan, Maka disini terdapat dua unsur inti yaitu kesamaan dan kebebasan.

Sebagai bentuk pemerintahan, demokrasi adalah suatu pemerintahan atau peraturan oleh rakyat sendiri, yang didasarkan atas lembaga-lembaga yang terdiri dari wakil-wakil rakyat yang dipilih secara bebas.

Seorang kepala pemerintahan atau ekskutif dipilih oleh rakyat dan eksekutif itu bertanggungjawab kepada rakyat atau wakilnya.

Dalam teori Barat demokrasi itu mempunyai dua pengertian, yaitu :

1. Sebagai demokrasi politik atau demokrasi ketatanegaraan (politicke of staatkundige democratic). Demokrasi politik menitik beratkan pada bentuk staatsorde itu sendiri, yaitu cara bagaimana rakyat ikut serta dalam urusan pemerintahan.

2. Sebagai demokrasi sosial atau ekonomi menitikberatkan pada persamaan hak dibidang sosia! dan ekonomi. (Agus, M. Mazwan, Sosrokusumo, 1983 : 12-13).

Prinsip Demokrasi ekonomi pada dasarnya lahir seiring dengan keberadaan Welfare State (Negara Hukum Baru/Negara Kesejahteraan ). Konsep dan praktek Political State maupun Legal State yang telah ada seblumnya banyak mem'inbulkan kesengsaraan rakyat, terutama rakyat golongan ekonomi lemah,

Sistem perekonomian liberalisme dan individualisme yang ada pada masa itu telah menciptakan ketidakmerataan pembagian pendapatan, terjadinya ketidakstabilan kehidupan ekonomi, terjadinya konsentrasi kekuasaan ekonomi sehingga memungkinkan terjadinya monopoli, terjadinya eksploitasi terhadap manusia, dan juga dengan kekayaannya disini kaum borjuis berhasil mendudukkan wakil-wakilnya di Parlemen, dan Parlemen inilah yang membuat aturan-aturan untuk menjadi hukum negara yang akan dilaksanakan oleh pemerintah. Maka secara otomatis 
aturan-aturan yang dibuatpun lebih berpijak kepada kepentingan kaum borjuis.

Karena ke,nyataan inilah maka pada pertengahan abad XIX di Eropa Barat lahir soal sosial (sociale kwestie) yaitu tunrutan untuk menghrntikan ketimpangan sosial dengan sistem ekonomi liberalnya, Konsep negara hukum lama diganti dengan konsep negara hukum baru yang lebih dinamis yang dikenal dengan Welfare State (negara kesejahteraan). Dalam Welfare State tugas negara tidak saja sebagai penjaga malam dan tidak boleh pasif, melainkan harus ikut aktif untuk turut serta dalam kegiatan masyarakat sehingga kesejahteraan masyarakat terjamin. Pemerintah harus memberikan perlindungan kepada warganya baik di bidang politik maupun dalam dibidang social dan ekonomi. Tugas pemerintah disertai tugas bestuurzorg yaitu penyelenggaraan kesejahteraan umum. (SF. Marbun \& Moh. Mahfud, 1987: 45)

Dengan demikian dalam kontek Welfare State ini dikaitkan dengan sistem perekonomian suatu negara biasanya dikenal dengan sistem ekonomi campuran (mixed system) atau Demokrasi Ekonomi.
Peranan negara dalam konsep negara kesejahteraan menurut Briggs adalah " ...to modify (he play of market force..." (... memodifikasikan berbagai kekuatan pasar...). Perlunya pengendalian dan pembatasan terhadap bekerjanya kekuatan-kekuatan pasar tersebut adalah untuk mengatasi unsurunsur negative yang tidak diharapkan sebagai hasil (outcome) atau akibat bekerjanya kekuatan-kekuatan pasar tersebut.(Johnny Ibrahim, 2007 : 31)

Menurut Goodin dalam negara kesejahteraan, campur tangan negara dalam mengatur pasar dilukiskan sebagai ..."a public intervention in private market economy..,"' (... campur tangan public dalam ekonomi pasar swasta). Tujuannya tidak lain adalah guna meningkatkan kesejahteraan umum (promoting public welfare) dan memaksimumkan kesejahteraan sosial (to maximize social welfare) sehingga memperkecil dampak kegagalan pasar (market failure) terhadap masyarakat yang disebabkan oleh apa yang disebut moral hazard dan penggunaan yang keliru terhadap berbagai sumber daya (misallocation of resources).

Selanjutnya menurut pendapat Sri Rejeki Hartono balnva, ada tiga asas 
penting yang dibutuhkan dalam rangka pembinaan cita hukum dari asas-asas hukum nasional, yaitu asas campur tangan negara terhadap kegiatan ekonomi, asas keseimbangan dan asas pengawasan publik. Kegiatan ekonomi yang terjadi dalam masyarakat membutuhkan campur tangan negara, mengingat tujuan dasar kegiatan ekonomi itu sendiri adalah untuk mencapai keuntungan. sasaran tersebut mendorong terjadinya penyimpangan bahkan kecurangan yang dapat merug-ikan pihak-pihak tcrtentu, bahkan semua pihak.

Campur tangan negara terhadap kegiatan ekonomi secara umum dalam rangka hubungan hukum yang terjadi tetap dalam batas-batas keseimbangan kepentingan umum semua pihak. Dengan demikian campur tangan negara adalah dalam rangka menjaga keseimbangan kepentingan semua pihak dalam masyarakat, melindungi kepentingan produsen dan konsumen, sekaligus juga untuk melindungi kepentingan negara dan kepentingan umum terhdap kepentingan perusahaan atau pribadi. (Johnny Ibrahim, $2007: 35)$
Dalam konteks ekonomi campuran, Friedmann tnenguraikan empat fungsi negara, pertama negara sebagai penyedia (provider), dalam kapasitas tersebut dilaksanakan upaya-upaya untuk memenuhi standart minimal yang diperlukan masyarakat dalam rangka mengurangi dampak pasar bebas yang clapat incrugikan masyarnkat. Kedtia fungsi negara sebagai pengatur (regulator) untuk menjamin ketertiban agar tidak muncul kekacauan. Ketiga, fungsi negara untuk eampur tangan langsung dalam perekonomian (entrepreneur) dan keempat fungsi negara sebagai pengawas (umpire) yang berkaitan dengan berbagai produk aturan hukum untuk menjaga ketertiban dan keadilan sekaligus bertindak sebagai penegak hukum. Selanjutnya menurut Friedmann bahwa eampur tangan negara disini lebih bersifat sebagai pengatur (the welfare -regulatory state) (Johnny Ibrahim. 2007 : 36)

Selanjutnya jika kita memperhatikan kondisi di Indonesia seperti apa yang telah ditegaskan dalam UUD 1945 khususnya dalam Pasal 1 ayat 3 bahwa, Negara Indonesia adalah negara hukum. Jika dikaitkan dengan ruang lingkup tugas 
pemerintaan maka secara filosofis konstitusional jelas bahwa Indonesia menganut prinsip negara hukum yang dinamis atau welfare state (negara kesejahteraan). Hal ini bisa dilihat dari pernyataan yang tertuang dalam Pembukaan UUD 1945 alenea keempat yang memuat tujuan negara yaitu melindungi segenap bangsa Indonesia dan seluruh tumpah darah Indonesia, memajukan kesejahteraan umum, men-cerdaskan kehidupan bangsa dan ikut melaksanakan ketertiban dunia yang berdasarkan kemerdekaan, perdamaian abudi dan keadilan sosial. Selain itu juga sila kelima dari Pancasila yang tercantum dalam alenea keempat Pembukaan UndangUndang Dasar 1945 yang menegaskan "keadilan social bagi seluruh rakyat Indonesia". Ketentuan dalam Pasal 27 ayat 2, Pasal 31, 33 dan 34 UndangUndang Dasar 1945 yang mengharuskan pemerintah Indonesia untuk menjamin kemakmuran rakyatnya.

Sedangkan sistem perekomonian Indonesia menganut Demokrasi Ekonomi dengan dasar asas kekeluargaan (Pasal 33 Undang-Undang Dasar 1945), dengan demikian kemakmuran tidak hanya untuk individu atau kelompok melainkan untuk semua orang. Demokrasi Ekonomi yang di-tegaskan dalam Pasal 33 ayat 4 Undang-Undang Dasar 1945 (setelah amandemen) tersebut dilaksanakan dengan prinsip ke-bersamaan, efisiensi berkeadilan, ber-kelanjutan, berwawasan lingkungan, kemandirian, serta dengan menjaga keseimbangan kemajuan dan kesatuan ekonomi nasional.

Hanya sangat disayangkan bahwa dalam Undang-Undang Dasar 1945 tidak mem-berikan pengertian tentang maksud prinsip-prinsip tersebut. Ketentuan ayat 5 menegaskan bahwa, ketentuan lebih lanjut mengenai pelaksanaan Pasal ini diatur dalam undang-undang. Menurut pendapat penulis ketentuan yang demikian bisa menimbulkan arti yang berbeda-beda, khususnya menyangkut pengertian prinsip-prinsip tersebut.

Sebagai suatu referensi barangkali kita perlu menyimak ketentuan yang tertuang dalam Garis-Garis Besar Haluan Negara (GBHN) bahwa, pembangunan ekonomi harus selalu mengarah kepada mantapnya sistem ekonomi nasional berdasarkan Pancasila dan Undang- 
Undang Dasar 1945 yang disusun untuk Mewujudkan Demokrasi Ekonomi yang harus menjadikan dasar pelaksanaan pembangunan yang memiliki cirri sebagai berikut:

a. Perekonomian disusun sebagai usaha bersama berdasar atas asas kekeluargaan.

b. Cabang-cabang produksi yang penting bagi negara dan yang menguasai hajat hidup orang banyak dikuasai oleh negara.

c. Bumi, air dan kekayaan alam yang terkandung di dalamnya sebagai pokok kemakmuran rakyat dikuasai oleh negara dan dipegunakan untuk sebesar-besarnya kemakmuran rakyat.

d. Sumber kekayaan dan keuangan negara dipergunakan dengan permufakatan lembaga perwakilan rakyat dan pengawasan terhadap kebijaksanaannya ada pada lembaga penvakilan rakyat pula.

e. Perkonomian daerah dikembangkan secara serasi dan seimbang antar daerah dalam satu kesatuan perekonomian nasional dengan mendaya- gunakan potensi dan peran serta daerah secara optimal dalam rangka mewujudkan Wawasan Nusantara dan Ketahanan Nasional.

f. Warganegara memiliki kebebasan dalm memilih pekejaan yang dikehendaki dan mempunyai hak akan pekerjaan dan penghidupan yang layak bagi kemanusiaan.

g. Hak milik perorangan diakui dan pemanfaatannya tidak boleh bertentangan dengan kepentingan masyarakat.

h. Potensi, inisiatif dan daya kreasi setiap warganegara; dikembangkan sepenuhnya dalam batas-batas yang tidak merugikan kepentingan umum.

i. Fakir miskin dan anak-anak terlantar dipeliharaoleh negara.

Selanjutnya dalam Demokrasi Ekonomi yang berdasarkan Pancasila harus dihindarkan hal-hal sebagai berikut:

a. Sistem free fight liberalism yang menimbulkan eksploitasi terhadap manusia dan bangsa lain yang dalam sejarahnya di 
Indonesia telah menimbulkan dan mempertahankan kelemahan structural ekonomi nasional dan posisi Indonesia dalam perekonomian dunia.

b. Sistem etatisme dalam art! bahwa negara beserta aparatur ekonomi negara bersifat dominant, mendesak dan mematikan potensi serta daya kreasi unit-unit ekonomi diluar sector negara, c. Persaingan tidak sehat serta pemusatan kekuatan ekonomi pada satu kelompok dalam bentuk monopoli dan monopsoni yang merugikan masyurakal dan bcrtentangan dengari cita-cila keacfilan sosial.

Dalam GBHN 1999-2004 menegaskan pula bahwa pembangunan ekonomi dibangun dengan berlandaskan sistem ekonomi kerakyatan. Komponen utama sistem Ekonomi Kerakyatan adalah sumberdaya manusia sebagai konsumen, sebagai tenaga kerja dan sebagai pengusaha serta sumberdaya alam dan lingkungan hidup termasuk tanah, air, udara dan lingkungan tempat sumberdaya manusia melakukan aktifitasnya.

Ciri-Ciri sistem ekonomi kerakyatan adalah :
1. Penegakan prinsip keadilan dan demokrasi ekonomi disertai kepedulian yang lemah.

2. Pemitraan, pemberdayaan dan prlindungan terhadap yang lemah oleh semua potensi bangsa, terutama pemerintah sesuai kernampuannya.

3. Penciptaan iklim persaingan usaha yang sehat dan intervensi yang ramah pasar.

4. Pemberdayaan kegiatan ekonomi rakyat terkait dengan upaya menggerakkan perekonomian pedesaan.

5. Pemanfaatan dan penggunaan tanah dan sumber daya alam lainnya seperti hutan, laut, udara dan mineral secara adil, transparan dan produktif degan mengutamakan hak-hak rakyat setempat, termasuk hak ulayat masyarakat adapt dengan tetap menjaga kelestarian fungsi lingkungan hidup.

\section{Konsep Keadilan}

Pemikiran tentang kcadiian pada dasarnya telah dimulai sejak jaman ' Yunani Kuno. Menurut Plato, keadilan 
adalah pembagian kerja yang diatur sesuai dengan bakat, bidang keahlian dan ketrampilan setiap warganegara. Pembagian kerja ini tidak hanya berlaku bagi salah satu kelas dalam negara melainkan berlaku untuk ketiga kelas sehingga setiap kelas dapat berfungsi sebagaimana mestinya. Plato mengatakan " The proper functioning of the money making class, the helpers and the guardians, each doing its own work in the stale ... would be justice and would render the city just. (Berfungsinya kelas yang menghasilkan uang, para pembantu dan para penjaga sebagaimana mestinya, yang masing-masing melakukan tugasnya di dalam negara merupakan keadilan yang akan menjadikan negara itu adil). (J.H. Rapar, 1991: 84)

Pandangan Aristoles bahwa keadilan menuntut perlakuan yang sama bagi mereka yang sederajat di depan hukum. Tetapi tetap menjadi urusan tatanan politik untuk menentukan siapa yang harus diperlakukan sama ataupun sebaliknya.

Menurut Thomas Aquinas, Keadilan diperlukan untuk mengatur hubungan antar manusia. Keadilan ini terdiri dari tiga bidang, yaitu keadilan distributif, yang mengatur hal-hal untum, keadilan komutatif, yang mengatur tentang keadilan yang mungkin muncul dalam tindakan tukar-menukar (bukan sama dengan tindakan balas dendam) dan keadilan legal yang mengatur keseluruhan kedua keadilan sebekumnya dalam aturan hukum (Antonius Cahyadi, E. Fernando M. Manuliang, 2007 : 51).

Keadilan menurut Hans Kelsen adalah suatu tertib social tertentu yang di bawah lindungannya usaha untuk mencari kebenaran bisa berkembang dengan subur, Keadilan adalah keadilan kemerdekaan, keadilan perdamaian, keadilan demokrasi keadilan toleransi.

Jonh Rawls mengkonsepkan keadilan sebagai suatu yang fairness, yang mengandung prinsip-prinsip bahwa orang-orang yang merdeka dan rasional yang mengejar kepentingan-kepentingannya hendaknya memperoleh posisi yang sama pada saat akan memulainya danitu merupakan syarat yang fundamental bagi mereka untuk memasuki asosiasi mereka. (John Rawls, 2006 :12).

Sesungguhnya masih banyak lag! konsep-konsep keadilan yang dikembangkan oleh para pemikir, tiap 
pemikir mempunya teorinya sendirisendiri yang satu sama lain berbeda. Hal ini disebabkan dari latar belakang keberadaan mereka dan pendekatan

Konsep keadilan di Indonesia dikembangankan dalam konteks sebagai negara hukum yang berlandaskan Pancasila dan Undang-Undang Dasar 1945.

\section{Konsep Kepastian Hukum}

Kepastian Hukum menurut Soedikno Mertokusumo, merupakan salali satu syarat yang harus dipenuhi dalam penegakan hukum. Kepastian Hukum menurut beliau adalah " perlindungan yustisiabel terhadap tindakan sewenang-wenang, yang berarti bahwa seseorang akan dapat rnemperoleh sesuatu yang diharapkan dalam keadaan tertentu."

Esensi Kepastian Hukum sesungguhnya adalah perlindungan dari tindakan sewenang-wenang, tidak saja dari negara melainkan juga oleh sekelompok pihak lain diluar negara.

Dalam memahami nilai Kepastian Hukum yang harus diperhatikan adalah bahwa nilai itu mempunyai relasi yang erat dengan instrument hukum yang positif danperanan negara dalam mengaktualisasikannya dalam hukum positif. Bahkan negara disini mempunyai tanggung jawab untuk menjalankan dan menegakkannnya. Hal inilah yang mendasari konsep Kepastian Hukum yang dirumuskan oleh Anton M. Moeliono dan Soedikno Mertokusumo.

Dalam perkembangan selanjutnya bahwa Kepastian Hukum harus menjadi nilai bagi setiap pihak dalam setiap sendi kehidupan di luar negara itu sendiri dalam penerapan hukum legislasi maupun yudikasi. Setiap orang atau pihak tidak diper-kenankan untuk bersikap tindak semena-mena.

\section{Penerapan Dalam Undang- Undang Nomor 25 Tahun 2007 tentang Penanaman Modal}

Undang-Undang Nomor 25 Tahun 2007 tentang Penanaman Modal ini terdiri dari 18 bab dan 40 Pasal, dengan penjelasan Pasal-Pasal.

Dalam ketentuan Undang-Undang penanaman Modal ini, yang dimaksud dengan Penanaman Modal adalah segala bentuk kegiatan penanaman modal, baik oleh penanam modal dalam negeri maupun penanam modal asing untuk melakukan usaha diwilayah negara 
Reuplik Indonesia.

Pengertian Modal disini me-liputi asset bentuk uang atau bentuk lain yang bukan uang yang dimiliki oleh penanam modal yang mem-punyai nilai ekonomis.

Secara substansi UndangUndang Penanaman Modal ini bertujuan untuk:

1. Meningkatkan pertumbuhan ekonomi nasional

2. Menciptakan lapangan kerja

3. Meningkatkan pembangunan ekonomi berkelanjutan

4. Meningkatkan kemampuan daya saing dunia usaha nasional.

5. Meningkatkan kapasitas dan kemampuan teknologi nasional

6. Mendorong pengembnngan ekonomi kerakyatan.

7. Mengolah ekonomi potensial menjadi kekuatan ekonomi riil dengan menggunakan dana yang berasal baik dari dalam negeri maupun luar negeri;

8. Meningkatkan kesejahteraan dalam masyarakat.

Tujuan tersebut dapat tercapai apabila didukung dengan sarana dan prasarana fasilitas penanaman modal yang memadai terutama dengan meng- hilangkan factor-faktor penghambat dalam penanaman modal selama ini, yakni menciptakan adanya perlindungan hukum dan kepastian hukum dalam penanaman modal, penciptaan birokrasi yang efisien dan tidak memakan biaya tinggi, adanya koordinasi antar instansi baik dipusat maupun di daerah, jaminan keamanan berusaha serta menciptakan iklim yang kondusif dalam bidang ketenagakerjaan.

Dalam penyelenggaraan penanaman modal, ketentuan Pasal 3 ayat UndangUndang Penanaman Modal menegaskan bahwa; Penanaman modal diselenggarakan berdasar :

a.kepastian hukum

b.keterbukaan,

c. akuntabilitas,

d.perlakuan yang sama dan tidak membedakan asal negara,

e.kebersamaan;

f. efisiensi berkeadilan;

g.berkelanjutan;

h.berwawasan lingkungan;

i. kemandirian;

j. keseimbangan kemajuan dan kesatuan ekonomi nasional.

Sesuai dengan asas perlakuan yang sama dan tidak membedakan asal 
negara Undang-Undang ini memberikan hak, kewajiban, tanggung-jawab maupun fasilitas yang sama kepada penanam modal. Pemberian fasilitas Hak Guna Usaha ( HGU) selama 95 tahun, Hak Guna Bangunan (HGB) selama 80 tahun dan Hak Pakai selama 70 tahun (Pasal 22 ayat 1) memberkan konsekwensi yang besar baik dari segi yuridis, sosiologis maupun filosofis. Bahwa ketentuan tersebut bertentangan dengan UndangUndang No. 5 tahun 1960 tentang Peraturan Dasar Pokok-Pokok Agraria (UUPA).

Dalam UUPA mengatur bahwa lama HGU 60 tahun, HGB 50 tahun dan Hak Pakai selama jangka waktu tertentu atau selama tanahnya dipergunakan untuk keperluan tertentu. Secara sosiologis penerapan Pasal ini juga dapat menimbulkan ketimpangan sosial dalam masyarakat, tujuan yang hendak dicapai oleh undang-undang ini akan semakin sulit dicapai. Karena justru akan menimbulkan liberalisme baru di Indonesia.

Secara filosofis sangat bertentangan dengan jiwa Pancasila dan Undang-Undang Dasar 1945, Undang-
Undang Penanaman Modal ini juga nampaknya juga mengedepankan asas kepastian hukum dan efisiensi berkeadilan (Pasal 3 ayat 1). Dalam penjelasannya yang dimaksudkan dengan asas kepastian hukum adalah asas dalam negara hukum yang meletakkan hukum dan ketentuan peraturan perundangan-undangan sebagai dasar dalam setiap kebijakan dan tindakan dalam bidang penanaman modal. Sedangkan asas efisiensi ber-keadilan adalah asas yang mendasari pelaksanaan penanaman modal dengan mengedepankan efisiensi berkeadilan dalam usaha untuk mewujudkan iklim usaha yang adil, kondisif, dan berdaya saing

Apabila dilihat dari sisi kepentingan, nampak bahwa kedua asas tersebut lebih berpihak pada kepentingan penanam modal, khususnya penanam modal besar. Scmentara kepentingan rakyat kecil (petani) juga pengusaha kecil sama sekali tidak terlindungi. Negara dalam hal ini pemerintah sebagai pihak yang seharusnya memberikan perlindungan dan juga sebagai pihak yang harus melaksanakan tugas pen- 
yelenggaraan kesejahteraan umum diabaikan.

\section{PENUTUP}

Prinsip demokrasi ekonomi yang berdasakan Pancasila dan UUD 1945 nampaknya hanya sebagai syarat formil saja, dalam ketentuan Pasal 22 Undang Undang No. 25 Tahun 2007 tentang Penanaman Modal ini justru dalam praktek sangat bertentangan dengan jiwa Pancasila dan UUD 1945. Demikian juga asas kepastian hukum maupun keadilan hanya mementingkan penanam modal saja.

\section{DAFTAR PUSTAKA}

Agus M. Mazwan Sosrokusumo, 1983, Fries Ermessen, Depdikbud. Universitas Jember, Jember.

Antonius Cahyadi \& E. Fernando $M$. Manullang, 2007, Pengantar ke Filsafat Hukum, Kencana Prenada Media Group, Jakarta.
Johnny lbrahim, 2007, Hukum Persaingan Usaha, Filosofi, Teori dan Implikasi Penerapannya di Indonesia, Bayu Media Publishing, Malang.

John Rawl, A Theory of Justice, 2007, Teori Keadilan. Pustaka Pelajar, Yogyakarta,

J, H. Rapar, 1991, Filsafat Politik Plato, Rajawali Press, Jakarta.

S.F. Marbun \& Moh. Mahfud M.D., 1982, Pokok Pokok Hukum Administrasi Negara, Liberty, Yogyakarta.

W. Friedmann, 1996, Teori \& Filsafat Hukum, Telaah Kritis Atas TeoriTeori Hukum Susunan I, PT. Raja Grafindo Persada, Jakarta.

\section{PERATURAN PERUNDANGAN}

Undang-Uridang Dasar 1945 Garis-Garis Besar Haluan Negara (GBHN) 1993.

Garis-Garis Besar Haluan Negara (GBHN) 1999-2004 Undang-Undang No. 25 Tahun 2007 tentang Penanaman Modal. 